\title{
Advances in Microalloyed Steels
}

\author{
Pello Uranga ${ }^{1,2}$ D \\ 1 CEIT, M. Lardizabal 15, 20018 Donostia-San Sebastian, Basque Country, Spain; puranga@ceit.es \\ 2 Universidad de Navarra, Tecnun, M. Lardizabal 13, 20018 Donostia-San Sebastian, Basque Country, Spain
}

Received: 22 February 2019; Accepted: 27 February 2019; Published: 28 February 2019

\section{Introduction}

Microalloyed steels are one of the core alloy steels in the development of modern advanced high-strength steels. Current developments are mostly focused on the optimization of their chemical composition and process parameters to achieve the microstructures needed to fulfill the most challenging mechanical properties and performance requirements. Understanding and controlling the microstructural parameters on the basis of chemical composition strategies (i.e., proper microalloying selection) and process optimization, require a proper comprehension of the mechanisms acting during hot working and final cooling. The development of new modelling tools and powerful characterization techniques will allow the scientific community to gain fundamental knowledge and evolve towards successful products for end-users.

\section{Contributions}

The present Special Issue on Advances in Microalloyed Steels includes two review papers [1,2] and nine research papers [3-11]. In all of them, different combinations of microalloying elements are analyzed in terms of process, microstructure, and mechanical property modification. The alternatives in microalloying are clearly reflected in terms of the grades studied in the different papers. $\mathrm{Nb}$ is present in many of them [1,2,5,7,8,10,11], alone or in combination with Mo [2,5,10], Ti [8], and V [10]. Two papers deal with Ti-Mo combinations [6,9], and the last two articles analyze the addition of V [4] and $\mathrm{Al}$ [3] as microalloying elements. Microalloyed grades are currently used in different sectors such as energy and structural and automotive sectors. The structural and automotive sectors are the most represented in this Special Issue.

Even if some papers cover specific performance problems and optimization alternatives for industrial processing conditions $[1,2,7,11]$, most of the papers deal with more fundamental analyses of the relationship between microstructure and mechanical properties [4-6,8,10]. Some papers also analyze the effect of microalloying on hot and cold working behaviors $[3,9]$.

\section{Conclusions and Outlook}

The development of microalloying technology has been impressive in the last 50 years. Nowadays, microalloyed steel grades can compete, with their lower costs, with other alloys with high-strength qualities. These developments, though, request a high level of intensive research and transferability to the industry and the understanding of basic mechanisms, which with a proper processing control, will ensure the reliability of these grades under the most challenging operational conditions. The interest and high level of the contributions published in this Special Issue ensure that the link between research and industry will not break anytime soon.

As a guest editor, I would like to express my sincere thanks to all the authors for submitting their manuscripts and sharing their latest developments. I also would like to encourage them and the rest of the community to keep on researching and publishing in steel-related topics, as their relevance to industry and society is and will be vital for progress in the future. 
Conflicts of Interest: The author declares no conflict of interest.

\section{References}

1. Villalobos, J.; Del-Pozo, A.; Campillo, B.; Mayen, J.; Serna, S. Microalloyed Steels through History until 2018: Review of Chemical Composition, Processing and Hydrogen Service. Metals 2018, 8, 351. [CrossRef]

2. Mohrbacher, H. Property Optimization in As-Quenched Martensitic Steel by Molybdenum and Niobium Alloying. Metals 2018, 8, 234. [CrossRef]

3. Zhang, X.; Matsuura, K.; Ohno, M. Effect of Cold-Deformation on Austenite Grain Growth Behavior in Solution-Treated Low Alloy Steel. Metals 2018, 8, 1004. [CrossRef]

4. Wang, P.; Li, Z.; Lin, G.; Zhou, S.; Yang, C.; Yong, Q. Influence of Vanadium on the Microstructure and Mechanical Properties of Medium-Carbon Steels for Wheels. Metals 2018, 8, 978. [CrossRef]

5. Maetz, J.; Militzer, M.; Chen, Y.; Yang, J.; Goo, N.; Kim, S.; Jian, B.; Mohrbacher, H. Modeling of Precipitation Hardening during Coiling of Nb-Mo Steels. Metals 2018, 8, 758. [CrossRef]

6. Larzabal, G.; Isasti, N.; Rodriguez-Ibabe, J.; Uranga, P. Effect of Microstructure on Post-Rolling Induction Treatment in a Low C Ti-Mo Microalloyed Steel. Metals 2018, 8, 694. [CrossRef]

7. Jansto, S. The Integration of Process and Product Metallurgy in Niobium Bearing Steels. Metals 2018, 8, 671. [CrossRef]

8. Eisenhut, L.; Fell, J.; Motz, C. Local Characterization of Precipitation and Correlation with the Prior Austenitic Microstructure in Nb-Ti-Microalloyed Steel by SEM and AFM Methods. Metals 2018, 8, 636. [CrossRef]

9. Wu, C.; Cai, M.; Yang, P.; Su, J.; Guo, X. Physically-Based Modeling and Characterization of Hot Flow Behavior in an Interphase-Precipitated Ti-Mo Microalloyed Steel. Metals 2018, 8, 243. [CrossRef]

10. Kostryzhev, A.; Singh, N.; Chen, L.; Killmore, C.; Pereloma, E. Comparative Effect of Mo and Cr on Microstructure and Mechanical Properties in NbV-Microalloyed Bainitic Steels. Metals 2018, 8, 134. [CrossRef]

11. Torkamani, H.; Raygan, S.; Mateo, C.; Rassizadehghani, J.; Vivas, J.; Palizdar, Y.; San-Martin, D. The Influence of La and Ce Addition on Inclusion Modification in Cast Niobium Microalloyed Steels. Metals 2017, 7, 377. [CrossRef]

(C) 2019 by the author. Licensee MDPI, Basel, Switzerland. This article is an open access article distributed under the terms and conditions of the Creative Commons Attribution (CC BY) license (http:/ / creativecommons.org/licenses/by/4.0/). 